\title{
EFEK PERBEDAAN JENIS ALPUKAT DAN GULA TERHADAP MUTU SELAI BUAH
}

\section{Effect of Different Kind of Avocado and Sugar on Quality of Fruit Jam}

\author{
Inda Three Anova* dan Kamsina \\ Balai Riset dan Standardisasi Industri Padang \\ JI. Raya LIK No. 23 Ulu Gadut Padang 25164 \\ *e-mail: indova99@gmail.com
}

Diterima: 5 Februari 2013, revisi akhir: 9 Juli 2013 dan disetujui untuk diterbitkan: 28 Agustus 2013

\section{ABSTRAK}

Buah alpukat merupakan buah yang sangat digemari karena banyak mengandung vitamin dan mineral. Selama ini buah alpukat lebih banyak dikonsumsi dalam bentuk segar atau jus dan jarang diolah menjadi produk olahan. Buah alpukat mudah sekali mengalami kerusakan dalam penyimpanannya sehingga perlu dilakukan pengolahan agar ketersediaanya tetap terjaga, misalnya dengan mengolah menjadi selai. Pembuatan selai umumnya menggunakan gula pasir, namun dapat juga mengunakan gula aren. Gula aren memiliki rasa aroma yang khas sehingga dapat mengurangi rasa pahit dari alpukat. Penelitian dilakukan dengan variasi perlakuan pemakaian jenis buah alpukat yaitu alpukat hijau bulat (Porsea americana Mill) dan alpukat hijau panjang (Porsea gratissima Gaertn) dengan jenis gula, yaitu gula pasir dan gula aren. Selai yang didapatkan selanjutnya diuji kadar air, kadar gula, padatan terlarut, kadar abu, kadar lemak dan tingkat kesukaan panelis terhadap warna, aroma, rasa dan uji mikrobiologi. Hasil penelitian menunjukkan bahwa produk selai dengan jenis alpukat hijau bulat (Porsea americana Mill) dan pemakaian gula aren disukai dari organoleptik warna, rasa, dan aroma, dengan kadar air 31,18\%, kadar gula 50,19\%, padatan terlarut $68,82 \%$, kadar abu $0,63 \%$, kadar lemak 8,48\%, cemaran mikoba ALT $<10 \mathrm{kol} / \mathrm{g}$, bakteri coliform $<3$ APM $/ \mathrm{g}$, kapang khamir $<10$ $\mathrm{kol} / \mathrm{g}$, dan memenuhi Standar Nasional Indonesia untuk selai buah, SNI 3746:2008.

\section{Kata Kunci : Selai buah, alpukat, gula aren}

\section{ABSTRACT}

Avocado is a very popular fruit because it contains a lot of vitamins and minerals. It is more consumed in the form of fresh or juice at this time and is rarely treated into processed products. Avocado is easily decay in storage so that is necessary to be processed in order to keep the availability, for example by processing into jam. The making of jam generally use granulated sugar, however it can also use palm sugar. Palm sugar has a specific taste and flavor that can reduce the bitter taste of avocado. The study was conducted with a variety of treatments that used round green avocado (Porsea americana Mill) and long green avocado (Porsea gratissima Gaertn) with type of sugar, the granulated sugar and brown palm sugar. The resulted of jam then analyzed the moisture content, sugar content, soluble solids, ash content, fat content and level of panelists preference for color, aroma, flavor and microbiological testing. The results showed that the jam products that was made of round green avocado (Porsea americana Mill) with the use of palm sugar was preferably for organoleptic of color, flavor, and aroma, with $31,18 \%$ water content, $50.19 \%$ sugar content, $68,82 \%$ dissolved solids, $0.63 \%$ ash content, $8.48 \%$ fat content, microbe contamination of total plate count $<10 \mathrm{col} / \mathrm{g}$, coliform bacteria $<3 \mathrm{MPN} / \mathrm{g}$, mold yeast $<$ $10 \mathrm{col} / \mathrm{g}$, and meet the Indonesian National Standard for fruit jam, SNI 3746:2008.

Keywords: Fruitjam, avocado, palm sugar 


\section{PENDAHULUAN}

Alpukat merupakan salah satu jenis buah yang berpotensi di Indonesia. Buah alpukat memiliki pasar dan nilai ekonomi yang sangat baik di dalam maupun luar negeri. Seiring dengan meningkatnya jumlah penduduk, permintaan terhadap buah alpukat juga semakin bertambah. Produksi buah alpukat Indonesia mengalami peningkatan dari tahun 2004 hingga 2009, dimana pada tahun 2004 hanya sebesar 221.774 ton dan pada tahun 2009 sebesar 257.642 ton (Badan Pusat Statistik, 2010).

Alpukat mengandung zat lemak yang tinggi, rasa yang khas serta flavor yang lembut, menyebabkan buah alpukat mempunyai cita rasa yang tinggi. Alpukat juga memiliki mineral seperti kalsium $10 \mathrm{mg}$, fosfor $20 \mathrm{mg}$, protein 0,9 gram, nilai kalori 85, vitamin A $180 \mathrm{IU}$, vitamin C $13 \mathrm{mg}$ dan vitamin D 20 IU (Widyastuti dan Paimin, 1993).

Alpukat ada dua jenis yaitu alpukat hijau bundar (Porsea americana Mill) dan alpukat hijau panjang (Porsea gratissima Gaertn). Porsea amaricana Mill beratnya perbuah sekitar 0,3 kg. Bentuknya bulat, buah muda berwarna hijau tua, sedangkan buah tua berwarna hijau tetapi warnanya lebih muda dan agak kusam daripada buah yang muda. Kulitnya agak kasar, daging buah tebal dan berwarna kehijauan atau kuning seperti mentega, sehingga lebih dikenal sebagai alpukat mentega. Porsea gratissima Gaertn berat buahnya sekitar $0,38 \mathrm{~kg}$. Leher buah panjang, kulit buahnya berwarna hijau dan licin. Daging buah tebal dengan rasa gurih (Widyastuti dan Paimin, 1993).

Buah alpukat merupakan buah yang cepat rusak, tidak tahan disimpan pada suhu kamar dalam jangka waktu yang lama. Kecepatan kerusakan tergantung dari suhu penyimpanan, serta komposisi oksigen dan karbondioksida udara lingkungannya. Kerusakan tersebut dapat menyebabkan mutu buah alpukat yang akan diekspor menjadi turun. Penurunan mutu buah dapat terjadi pada proses penyimpanan, yaitu buah busuk dan rusak sehingga tidak layak lagi untuk dikonsumsi, karena buah alpukat kebanyakan dikonsumsi dalam bentuk segar dan olahan seperti jus. Oleh karena itu perlu dilakukan pembuatan produk alternatif untuk buah alpukat seperti selai. Buah yang dapat digunakan untuk pembuatan selai adalah buah yang masak dan tidak ada tanda-tanda busuk.

Menurut BSN (2008), selai buah adalah produk makanan semi basah, dibuat dari pengolahan bubur buah-buahan, gula, dengan atau tanpa penambahan makanan yang diizinkan.

Pada prinsipnya hampir semua jenis buah dapat dibuat selai, terutama buah yang mengandung pektin. Pektin adalah senyawa karbohidrat yang berguna untuk membuat gel (bentuk seperti bubur sangat kental) jika bereaksi dengan asam atau gula. Buah alpukat merupakan buah yang cukup tinggi kadar karbohidratnya yaitu sekitar 7,7\% (Direktorat Gizi Departemen Kesehatan, 1996). Setiap jenis alpukat mempunyai karbohidrat berbeda, sehingga tekstur selai yang dihasilkan juga akan berbeda.

Alpukat memiliki rasa yang khas (agak pahit). Porsea gratissima Gaertn memiliki rasa pahit yang lebih terasa jika dibandingkan dengan Porsea amaricana Mill, sehingga dalam penelitian ini digunakan dua macam jenis alpukat tersebut dan untuk mengurangi rasa pahit pada alpukat digunakan dua macam jenis gula yaitu gula pasir dan gula aren sebagai pengikat dan pemberi rasa manis. Pemakaian gula yang lebih banyak dalam pemasakan sangat berpengaruh terhadap selai. Untuk itu perlu adanya penelitian pembuatan selai alpukat guna mengetahui jenis alpukat yang cocok untuk dibuat selai dan gula yang sesuai, serta disukai dan digemari konsumen.

\section{METODOLOGI PENELITIAN}

Bahan yang diperlukan dalam penelitian ini meliputi buah alpukat, gula pasir, gula aren, mayonaise, air, kemasan plastik dan bahan kimia untuk pengujian.

Peralatan yang digunakan adalah peralatan pembuatan selai, alat kemasan yaitu sealer, peralatan pengujian seperti oven, dan lain-lain. 
Penelitian dilakukan menggunakan rancangan acak lengkap faktorial yang terdiri atas dua faktor, yakni :

$$
\begin{aligned}
\text { Faktor } A= & \text { Jenis Buah Alpukat } \\
\mathrm{A} 1= & \text { Jenis hijau bulat /Alpukat } \\
& \text { mentega (Porsea americana } \\
\text { A2 }= & \text { Jenill } \\
& \text { Jratissima Gaertn) }
\end{aligned}
$$

Faktor $\mathrm{B}=$ jenis gula $(65 \%$ dari bubur buah)

$\mathrm{B} 1=$ gula pasir

$\mathrm{B} 2$ = gula aren

Masing-masing kombinasi perlakuan dilakukan dengan tiga kali ulangan. Data yang diperoleh diolah secara statistik dan uji lanjutan dengan DNMRT pada taraf nyata $5 \%$.

Proses pembuatan selai alpukat pada penelitian ini seperti terlihat pada Gambar 1.

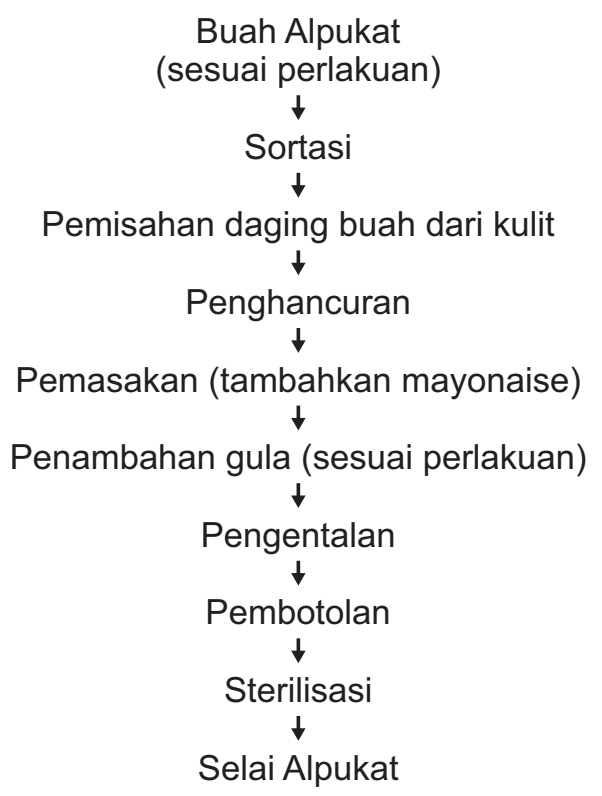

Gambar 1. Diagram alir pembuatan selai alpukat

Analisis kimia yang dilakukan terhadap produk selai yakni kadar air (metode gravimetri), kadar gula (metode titrimetri), padatan terlarut (metode gravimetri), kadar abu (metode gravimetri), kadar lemak (metode gravimetri) dan analisis mikrobiologi ALT, kapang/khamir (plate count) dan bakteri Coliform (APM).
Uji organoleptik dilakukan oleh 15 orang panelis berdasarkan tingkat kesukaan terhadap warna, aroma, dan rasa selai dengan skala nilai $1-5$ (tidak suka, kurang suka, cukup suka, suka, sangat suka).

\section{HASIL DAN PEMBAHASAN}

\section{Kadar Air}

Hasil analisa statistik terhadap kadar air selai alpukat menunjukkan variasi perlakuan jenis buah alpukat dan jenis gula berpengaruh sangat nyata. Perlakuan jenis alpukat Porsea gratissima Gaertn dengan gula aren (A2B2) memberikan kadar air tertinggi yaitu $32,7 \%$ dan yang terendah terdapat pada perlakuan jenis alpukat Porsea americana Mill dengan gula pasir (A1B1) dengan nilai 30,67\% seperti terlihat pada Gambar 2 .

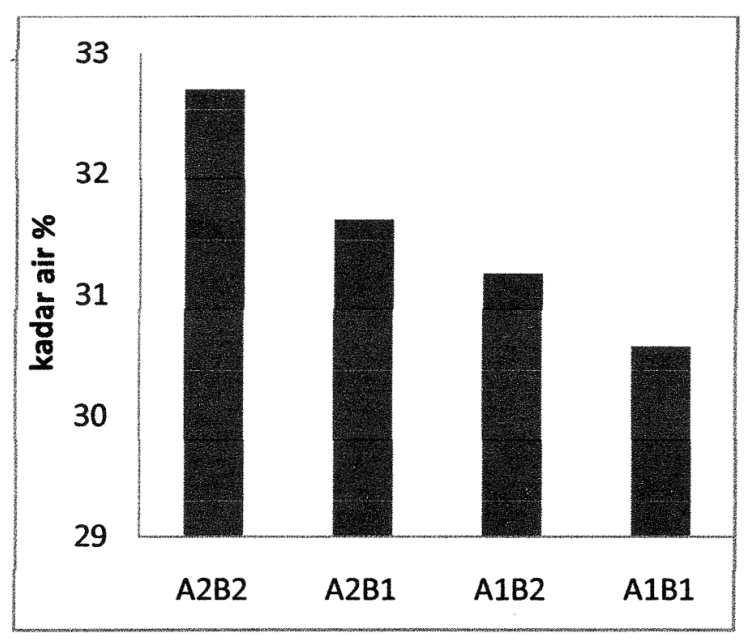

Ket : $\mathrm{A} 2 \mathrm{~B} 2$ = Porsea gratissima Gaertn, gula aren, $\mathrm{A} 2 \mathrm{~B} 1$ = Porsea gratissima Gaertn, gula pasir, A1B2 = Porsea amaricana Mill, gula aren, , A1B1 = Porsea Americana Mil, gula pasir.

Gambar 2. Kadar air selai alpukat

Berdasarkan hasil analisis kadar air di atas dapat dilihat bahwa terjadi penurunan kadar air dari buah alpukat setelah menjadi selai, dimana kadar air pada buah alpukat yaitu sekitar $84,3 \%$. Penurunan kadar air ini disebabkan oleh penguapan yang terjadi selama proses pemasakan, dan juga disebabkan karena berbedanya kadar air bahan baku yang digunakan, dimana kadar 
air pada jenis Porsea gratissima Gaertn $(84,3 \%)$ lebih tinggi dibandingkan jenis Porsea amaricana Mill $(82,6 \%)$ (Kalie, 1997). Menurut Sidauruk (2010) bahwa perbedaan juga bisa terjadi karena berbedanya jenis dan varitas dari buah tersebut. Kadar air gula aren juga lebih tinggi dibandingkan kadar air dari gula pasir, kadar air dari gula aren 3,0\% dan kadar air dari gula pasir 1\%. Gula/sukrosa merupakan senyawa higroskopis yang mampu mengikat air bebas menjadi air terikat yang sulit diuapkan pada saat pemasakan sehingga kadar air bahan baku yang lebih tinggi menyebabkan kadar air setelah menjadi selai lebih tinggi (Yulistiani, dkk.,2010).

Kadar air sangat menentukan mutu suatu bahan. Kandungan air dalam produk makanan akan mempengaruhi daya tahan produk makanan terhadap serangan mikroba. Air yang terdapat dalam bahan makanan akan dipergunakan oleh mikroorganisme untuk pertumbuhannya. Kadar air yang tinggi dalam bahan makanan akan menyebabkan produk makanan mudah rusak (Winarno, 1997).

\section{Kadar Gula}

Hasil analisis kadar gula dari perlakuan jenis alpukat dan jenis gula terhadap selai alpukat memberikan hasil seperti terlihat pada Gambar 3.

Dari Gambar 3 dapat dilihat bahwa kombinasi perlakuan jenis Porsea americana Mill dan jenis gula pasir (A1B1) memberikan nilai tertinggi untuk kadar gula yaitu $53,96 \%$, sedangkan kadar gula terendah terdapat pada kombinasi perlakuan jenis Porsea gratissima Gaertn dengan gula aren (A1B2) yaitu 50,20\%.

Terjadinya perbedaan kadar gula dari selai alpukat yang dihasilkan sangat dipengaruhi oleh jenis gula yang digunakan. Berbeda jenis gula berbeda kadar gulanya, walaupun dalam pembuatannya digunakan jumlah persentase berat gula yang sama. Dimana gula pasir (yang dihitung sebagai sakarosa) kadar gulanya $99 \%$, sedangkan gula aren kadar gulanya $77 \%$, sehingga kadar gula pada perlakuan dengan gula pasir memberikan kadar gula yang lebih tinggi dibanding dengan perlakuan yang memakai gula aren. Menurut Syahrumsyah, dkk (2010), tingkat kematangan buah juga mempengaruhi kadar gula dari selai buah yang dihasilkan.

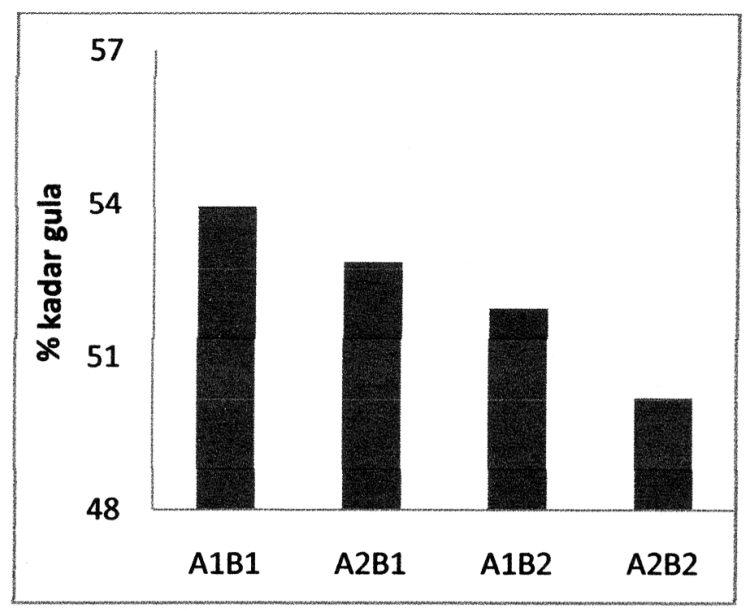

Ket : $\mathrm{A} 1 \mathrm{~B} 1$ = Porsea Americana Mill, gula pasir, A2B1 = Porsea gratissima Gaertn, gula pasir, A1B2 = Porsea amaricana Mill, gula aren, A2B2 = Porsea gratissima Gaertn, gula aren,

Gambar 3. Kadar gula selai alpukat

Gula disamping sebagai pemberi cita rasa juga berpengaruh terhadap kekentalan gel. Sifat ini disebabkan karena gula dapat menyerap air. Akibatnya pengembangan pati menjadi lebih lambat sehingga suhu gelatinisasi lebih tinggi. Gula menyebabkan gel lebih tahan dan awet (Hambali, et. al. 2004).

Menurut Winarno (1997), selama pemanasan sebagian sukrosa akan terurai menjadi gula invert (fruktosa dan glukosa). Gula berperan dalam proses dehidrasi yang membuat ikatan hidrogen pada pektin menjadi lebih kuat dan membentuk jaringan polisakarida, yaitu senyawa kompleks dimana air terperangkap dalam jaringan tersebut. Kekurangan gula akan membentuk gel yang kurang kuat pada semua tingkat keasaman sehingga membutuhkan lebih banyak asam untuk menguatkan strukturnya. Gula tidak ditambahkan di awal karena adanya pemanasan akan menyebabkan terjadinya pencoklatan karena waktu pemasakan lama. 


\section{Padatan Terlarut}

Hasil analisa padatan terlarut dari perlakuan jenis alpukat dan jenis gula terhadap selai alpukat memberikan hasil seperti terlihat pada Gambar 4.

Dari Gambar 4 dapat dilihat bahwa total padatan terlarut tertinggi terdapat pada perlakuan penggunaan jenis Porsea americana Mill dengan gula pasir yaitu $69,33 \%$ dan terendah terdapat pada perlakuan penggunaan jenis Porsea gratissima Gaertn dengan gula aren yaitu $67,30 \%$. Tingginya total padatan terlarut pada perlakuan (A1B1) sangat dipengaruhi oleh jenis gula yang digunakan yaitu gula pasir dengan kadar gula (yang dihitung sebagai sakarosa lebih tinggi) dimana menurut Winarno (2002) total padatan terlarut sangat dipengaruhi selain oleh pektin yang terdapat pada buah juga dipengaruhi oleh penambahan atau pemakaian gula pasir. Menurut Buckle (1987) semakin tinggi penambahan atau pemakaian sukrosa dapat menghasilkan total padatan terlarut yang lebih tinggi. Kandungan total padatan terlarut suatu bahan meliputi gula reduksi, gula non reduksi, asam organik, pektin dan protein (Desrosier, 1988).

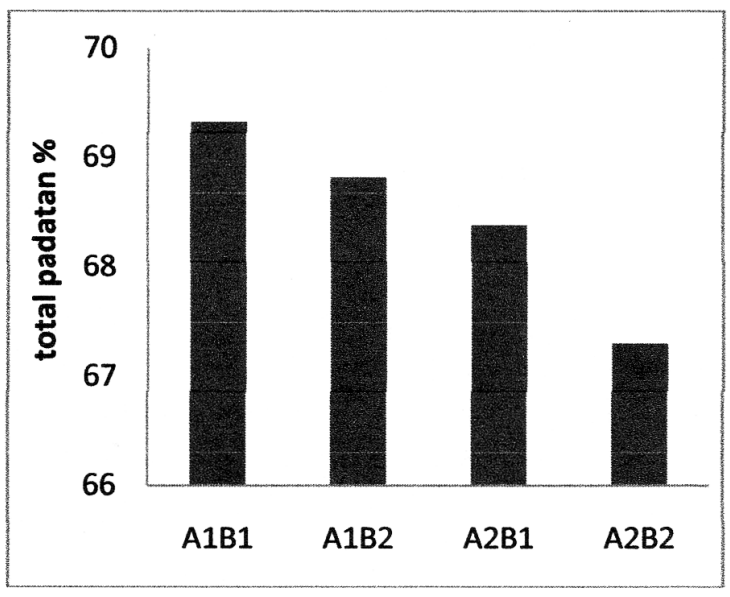

Ket : A1B1 = Porsea Americana Min, gula pasir, $\mathrm{A} 1 \mathrm{~B} 2$ = Porsea amaricana Min, gula aren, $\mathrm{A} 2 \mathrm{~B} 1$ = Porsea gratissima Gaertn, gula pasir, A2B2 = Porsea gratissima Gaertn, gula aren.

Gambar 4. Total padatan terlarut
Total padatan terlarut adalah zat padat dan residu yang dilarutkan dalam cairan, tetapi masih tetap setelah penguapan, sesuai dengan $\mathrm{SNI}$ selai buah syarat total padatan terlarutnya minimal $65 \%$, dimana selai alpukat yang dibuat dari semua perlakuan memenuhi persyaratan SNI tersebut.

\section{Kadar Abu}

Hasil analisa kadar abu dari perlakuan jenis alpukat dan jenis gula terhadap produk selai alpukat memberikan hasil yang tidak berbeda nyata, seperti terlihat pada Gambar 5.

Pada Gambar 5 dapat dilihat bahwa kadar abu paling tinggi terdapat pada perlakuan jenis Porsea gratissima Gaertn dengan gula pasir (A2B1) dan paling rendah pada perlakuan jenis Porsea americana Mill dengan gula aren (A1B1) dan berbeda tidak nyata dengan perlakuan lainnya. Tingginya kadar abu pada perlakuan A2B1 dapat disebabkan oleh perlakuan jenis alpukat dan gula, dimana kadar abu dari gula aren lebih tinggi dari kadar abu pada gula pasir dan tingkat kebersihan sewaktu bekerja. Menurut Winarno (2004), kadar abu dari suatu bahan sangat dipengaruhi oleh penggunaan bahan baku, bahan proses dan cara pengolahan yang dilakukan.

Kadar abu merupakan komponen kimia yang tidak terbakar dalam proses pengabuan seperti $\mathrm{SiO}_{2}$, logam-logam dan lain-lain. Efek ini lebih cenderung disebabkan oleh mutu bahan baku dan bahan proses yang digunakan serta tingkat kebersihan dalam proses pengolahan.

Kadar abu dari selai alpukat ini berkisar antara 0,62\%-0,65\%. Menurut Wiryadi (2007) kadar abu/mineral merupakan bagian berat mineral dari bahan yang didasarkan atas berat keringnya. Abu adalah zat organik yang tidak menguap, sisa dari proses pembakaran atau hasil oksidasi. Penentuan kadar abu ada hubungannya dengan mineral suatu bahan pangan. Mineral yang terdapat dalam bahan pangan terdiri dari 2 jenis garam, yaitu garam organik, misalnya asetat, pektat, mallat, dan garam anorganik, misalnya karbonat, fosfat, sulfat dan nitrat. 


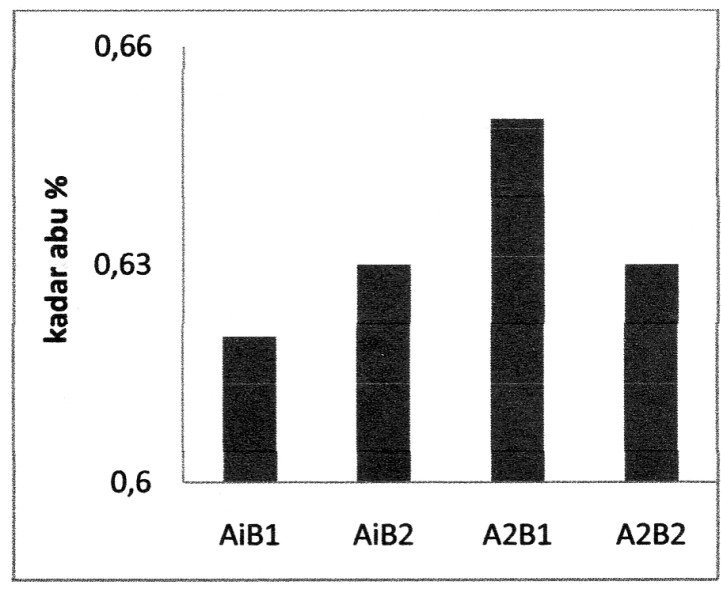

Ket : A1B1 = Porsea Americana Mill, gula pasir, A1B2 = Porsea amaricana Mill, gula aren, A2B1 = Porsea gratissima Gaertn, gula pasir, A2B2 = Porsea gratissima Gaertn, gula aren,

\section{Gambar 5. Kadar Abu Selai Alpukat}

Untuk menghindari adanya berbagai komponen abu yang mengalami dekomposisi atau bahkan menguap pada suhu tinggi maka suhu pengabuan disesuaikan dengan bahan. Untuk sampel selai, suhu yang disarankan adalah $525^{\circ} \mathrm{C}-$ $550{ }^{\circ} \mathrm{C}$ (Sudarmadji dkk, 1996).

\section{Kadar Lemak}

Hasil analisis kadar lemak dari perlakuan jenis alpukat dan jenis gula terhadap produk selai alpukat memberikan hasil yang berbeda tidak nyata, seperti terlihat pada Gambar 6.

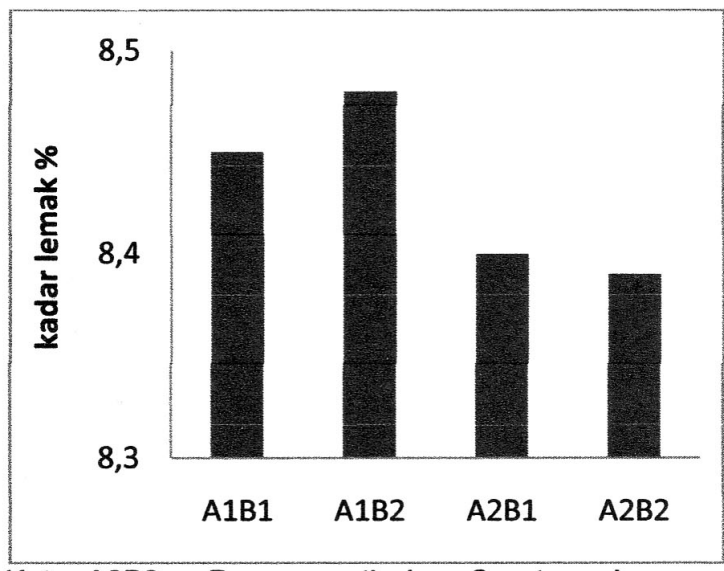

Ket : A2B2 = Porsea gratissima Gaertn, gula aren, A1B2 = Porsea amaricana Mill, gula aren, A2B1 = Porsea gratissima Gaertn, gula pasir, A1B1 = Porsea Americana Mill, gula pasir.

Gambar 6. Kadar lemak selai alpukat
Dari Gambar 6 dapat dilihat bahwa walaupun perlakuan jenis gula dan jenis alpukat tidak berpengaruh terhadap kadar lemak selai alpukat (berbeda tidak nyata) tetapi terjadi kenaikan kadar lemak total dari buah alpukat $(6,5 \%)$ setelah menjadi selai, dengan kadar lemak tertinggi pada perlakuan A1B2 dengan nilai $8,48 \%$ dan terendah pada perlakuan A2B2 dengan nilai $8,39 \%$. Terjadinya kenaikan kadar lemak total pada selai alpukat kemungkinan disebabkan karena pada proses pembuatan selai alpukat di tambahkan mayonaise yang bertujuan untuk memperbaiki tekstur dan menambah cita rasa, dimana penyusun utama mayonaise adalah lemak minyak.

Alpukat menyediakan jenis lemak sehat yang dibutuhkan tubuh. Seperti minyak zaitun, alpukat dapat meningkatkan kadar HDL (kolesterol "baik"). Kolesterol HDL dapat membantu melindungi terhadap kerusakan yang disebabkan oleh radikal bebas. Bahkan kolesterol tipe ini juga dapat membantu mengatur kadar trigliserida serta mencegah diabetes. Sebuah studi yang dilakukan di Canadian Medical Association Journal menemukan bahwa diet vegetarian, yang mencakup lemak HDL, dapat mengurangi kadar LDL ("buruk" kolesterol), (Mikail,2012).

\section{Uji Organoleptik Aroma, Warna dan Rasa}

Uji organoleptik yang dilakukan panelis terhadap produk selai alpukat meliputi warna, rasa, aroma dan tekstur dengan hasil seperti terlihat pada Gambar 7. Uji organoleptik warna, rasa dan aroma selai alpukat setelah dilakukan analisa statistik menunjukkan hasil yang berpengaruh tidak nyata pada semua perlakuan pembuatan selai apukat. Nilai organoleptik selai alpukat berkisar antara cukup disukai hingga disukai.

Dari Gambar 7 terlihat bahwa nilai rasa yang paling disukai panelis adalah perlakuan jenis Porsea americana Mill dan gula aren (A1B2). Hal ini kemungkinan disebabkan Porsea americana Mill memang terasa lebih gurih dan enak dibanding dengan Porsea gratissima Gaertn, serta dipengaruhi juga oleh rasa gula aren yang lebih spesifik. Komponen yang dapat menimbulkan rasa yang diinginkan tergantung dari senyawa penyusun, dan umumnya rasa bahan 
pangan tidak hanya terdiri dari satu macam, rasa, terpadu dari beberapa macam rasa, sehingga menimbulkan cita rasa yang utuh (Winarno, 2004) serta penerimaan suatu produk pangan tidak hanya dinilai dari sifat sensori rasa, maka sifat sensori lain yang berkaitan dengan mutu selai harus diperhatikan (Fatonah, 2003).

Nilai aroma yang paling disukai panelis adalah perlakuan dengan jenis alpukat Porsea america Mill dengan gula aren (A1B2). Tingginya nilai aroma pada perlakuan ini dapat disebabkan selain beraroma normal alami buah alpukat juga sangat dipengaruhi oleh gula aren yang digunakan. Gula aren mempunyai aroma yang lebih spesifik dibandingkan dengan gula pasir biasa. Komponen yang dapat menimbulkan aroma yang diinginkan tergantung dari senyawaan penyusun, dan tercium melalui indra penciuman.

Dari Gambar 7, juga dapat dilihat bahwa nilai aroma selai alpukat rata-rata disukai oleh panelis, diduga karena aroma selai alpukat masih terdapat aroma khas buah alpukat. Selanjutnya bahwa aroma atau flavour dalam makanan sangat dipengaruhi oleh jumlah bahan yang digunakan dan proses pengolahannya. Makanan yang memiliki aroma sedap dan khas akan mengundang selera konsumennya sebagai pembangkit selera seseorang (Facruddin, 1998).

Dari Gambar 7 dapat dilihat bahwa nilai warna yang paling disukai oleh panelis adalah selai dari jenis alpukat Porsea americana Mill dengan gula pasir, hal ini disebabkan karena selai yang dibuat dengan menggunakan gula pasir warnanya lebih cerah sedangkan selai yang dibuat dengan menggunakan gula aren, warnanya kurang cerah cenderung agak coklat karena gula aren berwarna agak coklat.

Daya tarik makanan sangat dipengaruhi oleh penampilan fisik atau warnanya. Hal ini merupakan salah satu faktor fisik yang menggugah selera orang untuk memilih makanan (Fachruddin, 1998). Ditambahkan oleh De Man (1997), bersama-sama dengan bau, rasa dan tekstur, warna memegang peranan penting dapat diterimanya suatu makanan. Warna makanan disebabkan oleh pigmen alam atau pewarna yang ditambahkan. Pigmen alam mencakup pigmen yang sudah terdapat dalam makanan dan pigmen yang terbentuk pada pemanasan, penyimpanan atau pemasakan.

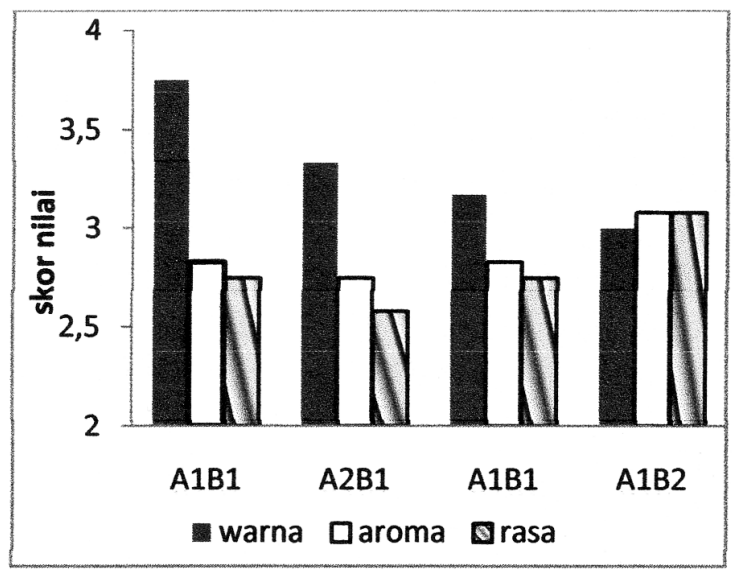

Ket : A2B2 = Porsea gratissima Gaertn, gula aren, A1B2 = Porsea amaricana Mill, gula aren, A2B1 = Porsea gratissima Gaertn), gula pasir, A1B1 = Porsea Americana Mill, gula pasir.

Gambar 7. Nilai organoleptik selai alpukat

Demikian juga Winarno (2002)., Wonggo (2010) menyatakan bahwa suatu bahan pangan yang bergizi, enak, dan teksturnya sangat baik tidak akan dimakan apabila warna tidak sedap dipandang atau memberi kesan telah menyimpang dari warna aslinya.

\section{Uji Mikrobiologi Selai Alpukat}

Berdasarkan hasil analisa mikrobiologi dari semua kombinasi perlakuan jenis alpukat dan perbandingan buah segar alpukat dengan gula, maka untuk analisa Angka Lempeng Total dan kapang khamir menunjukkan hasil analisa nol koloni/gram $(<10)$, demikian juga untuk bakteri Coliform hasilnya negatif (<3APM/gram).

Berdasarkan SNI 01-3746-2008 mengenai selai buah, maka cemaran mikroba untuk selai alpukat dari semua perlakuan adalah memenuhi standar, dimana untuk selai disyaratkan angka lempeng total maksimal $5 \times 10^{2}$ koloni/g, bakteri coliform $<3 \mathrm{APM} / \mathrm{g}$ serta kapang dan khamir maksimal 50 koloni/g. Menurut Satuhu (1994) bahwa gula disamping untuk memberikan rasa manis juga untuk mencegah tumbuhnya mikroorganisme. 
Menurut Fardiaz (1992), pertumbuhan mikroba dalam makanan sangat dipengaruhi oleh jumlah air yang tersedia. Semakin tinggi jumlah air yang tersedia (aw) untuk pertumbuhan mikroba maka semakin berkembang mikroba pada bahan tersebut. Supardi (1992), menambahkan bahwa bahan makanan dengan kadar air rendah lebih tahan karena kandungan air yang ada tidak dapat digunakan untuk aktivitas hidup mikroba sehingga miroba dalam bahan menjadi tidak aktif.

Disamping itu gula pada konsentrasi $65 \%$ akan lebih mengawetkan makanan dan menurunkan aktivitas air dari bahan pangan dan mencegah pertumbuhan organisme (Hermana, 1991, Noerhartati, dkk (2009).

\section{KESIMPULAN DAN SARAN}

\section{Kesimpulan}

Dari perlakuan jenis alpukat dan jenis gula terhadap selai alpukat diperoleh kesimpulan bahwa selai alpukat yang dibuat dengan variasi jenis Porsea americana Mill dan Porsea gratissima Gaertn dan pemakaian gula (pasir dan aren) sebanyak $65 \%$ dari berat bubur buah, memenuhi SNI 01-3746-2008 untuk selai buah. Pembuatan selai alpukat dengan variasi perlakuan jenis Porsea americana Mill dengan gula aren (A1B2) memberikan hasil yang optimal dengan warna, rasa, dan aroma disukai, kadar air $31,18 \%$, gula $50,19 \%$, total padatan terlarut $68,82 \%$, kadar abu 0,63\%, kadar lemak 8,48\%. Uji mikrobiologi ALT dan Kapang/khamir <10 koloni/gram, bakteri Coliform <3 APM/gram.

\section{DAFTAR PUSTAKA}

Badan Pusat Statistik. 2010. Produksi Buahbuahan di Indonesia. BPS. Jakarta.

Buckle. 1987. Ilmu Pangan. Universitas Indonesia Press Edisi kedua. Jakarta.

Desrosier N. W. 1988. Teknologi Pengawetan Pangan. Universitas Indonesia Press. Jakarta.

Dewan Standardisasi Nasional. 2008. SNI 01-3746-2008. Selai Buah. Dewan Standardisasi Nasional. Jakarta.
De Man, Jon M. 1997. Kimia Makanan. Penerbit ITB. Bandung

Direktorat Gizi. Departemen Kesehatan RI. 1996. Daftar Komposisi Bahan Makanan. Jakarta . Bhratara Niaga Media.

Fachruddin, L. 1998. Memilih dan memanfaatkan bahan tambahan makanan. PT Trubus Agriwidya. Bogor.

Fardiaz. 1992. Mikrobiologi Pangan. PT. Gramedia. Jakarta.

Fatonah, W. 2003. Optimasi Produk Selai dengan Bahan Baku Ubi Jalar Cilembu. Skripsi Sarjana Teknologi Pertanian. IPB. Bogor.

Hambali, E., Suryani, A., dan Wadli. 2004. Membuat Aneka Olahan Rumput laut. Kanisius. Yogyakarta.

Hermana. 1991. Irradiasi Pangan. ITB. Bandung

Kalie, M Baga.1997. Alpukat budidaya dan pemanfaatannya. Kanisius. Yogyakarta.

Mikail, B. 2012. 6 Nutrisi Berkhasiat dari Alpukat. Kompas/201/01/06.Jakarta.

Noerhartati, E. 2009. Pembuatan Selai Salak. Jurnal Fakultas Teknik Universitas Wijaya Kusuma. Surabaya.

Satuhu, S. 1994. Penanganan dan Pengolahan Buah. PT. Penebar Swadaya. Jakarta.

Sudarmadji, S.,Haryono B., Suhardi., 1996. Analisis Bahan Makanan dan Pertanian. Yogyakarta: Pusat Antar Universitas Pangan dan Gizi Universitas Gajah.Mada. Liberty.

Supardi.1992. Kongres Nasional PERSAGI IX dan Kursus Penyegar IlmuGizi. Dewan Pimpinan Pusat, Persatuan Ahli Gizi Indonesia.Semarang. 
Syahrumsyah, H., et al. 2010. Pengaruh Penambahan Karboksil metal Selulose (CMC) dan Tingkat Kematangan Buah Nanas (Ananas comosus (L) Merr) terhadap Mutu Selai Nanas Vol. VI (6). Jurnal Teknologi Pertanian. Universitas Mulawarman. Samarinda.

Widyastuti, Y.E dan F.B. Paimin.1993. Mengenal buah Unggul Indonesia. Penebar Swadaya. Jakarta.

Winarno, F.G.1997.Kimia pangan dan gizi. PT. Gramedia Pustaka Utama. Jakarta.

Winarno, F.G. 2002. Kimia Pangan dan Gizi. PT. Gramedia Pustaka Utama.
Winarno, F.G.2004. Kimia Pangan dan Gizi. PT. Gramedia Pustaka Utama. Jakarta.

Wiryadi, R. 2007. Analisa Kadar Abu. PT Gramedia Pustaka Utama. Jakarta

Wonggo, D. 2010. Penerimaan Konsumen Terhadap Selai Rumput Laut (Kappaphycus alvarezii). Jurnal Perikanan dan Kelautan Vol. VI (1) April 2010.

Yulistiani, R,Murtiningsih, Munifa M. 2010. Peran Pektin dan Sukrosa pada Ubi Jalar Ungu. Jurnal Teknologi Pangan FTI. UPN. Jawa Timur. 